RESEARCH ARTICLE

\title{
Optimization of Copper Sulphate Levels to Enhance Yield and Quality of Aggregatum Onion (Allium cepa var aggregatum $L$ )
}

\author{
D. Jegadeeswari ${ }^{1 *}$, T. Chitdeshwari ${ }^{1}$ and A.K. Shukla ${ }^{2}$ \\ ${ }^{1}$ Department of Soil Science and Agricultural chemistry Tamil Nadu Agricultural University Coimbatore - 641003 \\ ${ }^{2}$ Indian Institute of Soil Science, Bhopal -462 038.
}

\begin{abstract}
Field experiments were conducted during rabi season of 2018 and summer season of 2019 at farmer's field, western zone of Tamil Nadu at Pattiyarkovilpathy, Theethipalayam and Narasipuram villages of Thondamuthur block of Coimbatore district. Totally five treatments comprising of varied $\mathrm{CuSO}_{4}$ levels $\left(0,2.5,5.0,7.5 \& 10.0 \mathrm{~kg} \mathrm{ha}^{-1}\right)$ were replicated four times in a randomized block design under irrigated conditions. The results showed that, fresh mean bulb yield of onion in four locations ranged from 12.4 to $15.6 \mathrm{t} \mathrm{ha}^{-1}$. The highest mean bulb yield of $15.6 \mathrm{t} \mathrm{ha}^{-1}$ was registered with recommended NPK $+5 \mathrm{~kg} \mathrm{CuSO}_{4} \mathrm{ha}^{-1}$ and the lowest mean bulb yield of $12.4 \mathrm{t} \mathrm{ha}^{-1}$ was recorded in NPK control with no $\mathrm{CuSO}_{4}$ addition. Dry Matter Production ranged from 1065 to $1199 \mathrm{~kg} \mathrm{ha}^{-1}$. The highest DMP of $1199 \mathrm{~kg}$ $\mathrm{ha}^{-1}$ was recorded in the treatment that was applied with $\mathrm{NPK}+5 \mathrm{~kg} \mathrm{CuSO}_{4}$ $\mathrm{ha}^{-1}$ and the lowest DMP (1065 $\left.\mathrm{kg} \mathrm{ha}^{-1}\right)$ was noticed with NPK control. Concerning copper content in bulb and foliage, it ranged from 6.09 to 12.3 and 8.46 to $13.7 \mathrm{mg} \mathrm{kg}^{-1}$ with the location mean of 6.16 to $12.0 \mathrm{mg} \mathrm{kg}^{-1}$ and 7.61 to $11.1 \mathrm{mg} \mathrm{kg}^{-1}$, respectively. Copper uptake in bulb and sheath varied from 7.05 to 18.3 and 6.26 to $11.0 \mathrm{~g} \mathrm{ha}^{-1}$ (mean of 8.55 to 12.3 and 6.52 to $10.4 \mathrm{~g} \mathrm{ha}^{-1}$ ), respectively with a total uptake of 14.1 to $27.6 \mathrm{~g} \mathrm{ha}^{-1}$. In both bulb and foliage, $\mathrm{Cu}$ content and uptake, increased with increasing doses of $\mathrm{CuSO}_{4}$ and the highest $\mathrm{Cu}$ content and uptake was registered with the application of $\mathrm{CuSO}_{4} @ 10.0 \mathrm{~kg} \mathrm{ha}^{-1}$. Regarding the availability of copper in soil, it ranged from 0.73 to $2.42 \mathrm{mg} \mathrm{kg}^{-1}$ and increasing levels of $\mathrm{CuSO}_{4}$ application increased the DTPA Cu status in soil and application of $10.0 \mathrm{~kg}$ $\mathrm{CuSO}_{4}$ ha $^{-1}$ recorded the highest copper availability in soil. Quality parameters viz., TSS, titrable acidity and ascorbic acid varied from 10.25 to $14.08^{\circ} \mathrm{Brix}$, 0.28 to $0.61 \%$ and 12.9 to 20.1 ( $100 \mathrm{~g}^{-1} \mathrm{FW}$ ), respectively. Field experiments conducted to optimize the rates of copper sulfate application to improve the yield and quality of aggregatum onion in four locations at Coimbatore district, showed that, soil application of $5 \mathrm{~kg} \mathrm{CuSO}_{4}$ along with recommended NPK @ 60:30:30 $\mathrm{kg} \mathrm{ha}^{-1}$ was found optimal for obtaining higher bulb yield (15.6 $\mathrm{t} \mathrm{ha}^{-1}$ ) and better quality in aggregatum onion with a $\mathrm{BC}$ ratio of 4.63 .
\end{abstract}

\section{Keywords: Aggregatum onion; Copper sulphate - optimization; yield; Quality}

\section{INTRODUCTION}

Onion (Allium cepa L.), belonging to the family Alliaceae, is one of the most important and popular vegetable spice crops cultivated worldwide (Mishra et al., 2013). It is famous for its characteristics flavour and is widely used to increase the taste of foods like gravies, soups, stew stuffing, fried fish, and meat (Rashid et al., 2016). The increased productivity with high quality onion is the utmost demand of the onion growers. Lack of micronutrients addition in the balanced fertilization schedule is one of the important causes for low yield and quality
(Lata Shukla et al., 2015). Onion requires a sufficient amount of plant nutrients and responds very well to the added nutrients (Alam et al., 20I0). Therefore, systematic fertilization of different micronutrients for onion cultivation is needed for the low organic matter and micronutrient deficient soils (Lata Shukla et al., 2015). Onion is more susceptible to nutrient deficiencies than most crop plants because of their shallow and unbranched root system; hence they require and often respond well to the addition of fertilizers (Brewester, 1994). Among the various factors affecting the yield of onion, adequate and 
balanced nutrient management plays a major role to optimising the quality and quantity of harvested plant products (Lakshmi and Sekhar, 2018). Nutrient management involves using crop nutrients as efficiently as possible to improve productivity while protecting the environment. The key fundamental principle behind nutrient management is balancing soil nutrient inputs with crop requirements (Khalid Mahmud Khokhar, 2019). Among all the essential nutrients, micronutrients viz., Fe, Mn, Zn, Cu, B and Mo are important for the optimal growth and productivity of the plants. Though these elements are required in small amounts, they are very important for plant development and for profitable crop production because they act as activators of many plant functions. Micronutrients among essential elements, plays a catalytic role in nutrient absorption and balancing other nutrients (Singh and Kalloo, 2000, Poongothai and Chitdeshwari, 2003). Although the requirement of a micronutrient is small compared to macronutrients, nevertheless, micronutrient deficiency can limit crop growth and production. Furthermore, micronutrients help increase the efficiency of the use of macronutrients. Micronutrients have a great role in the fertilizer program to achieve higher and sustainable crop yields (Vijay Aske et al., 2017 and Jegadeeswari et al., 2019). Among the micronutrients, copper is important element for plant growth because it acts as a catalyzer of several plant processes, imparts disease resistance in plants, indirect role in chlorophyll production, intensifies the color and flavor of fruits and vegetables and playing an irreplaceable role in the function of a large number of enzymes which catalyze oxidative reactions in a variety of metabolic pathways. Cu can also be considered as a toxic element whose deleterious effects usually arise at high concentrations (Donghua Liu et al., 1994). The copper deficiency interferes with protein synthesis and causes a buildup of soluble nitrogen compounds. Normal plants contain 8 to $20 \mathrm{mg} \mathrm{kg}^{-1}$ copper and deficient plants usually contain less than $6 \mathrm{mg} \mathrm{kg}^{-1}$. Copper deficiency in many plants shows up as wilting or lack of turgor and development of a bluish green tint before leaf tips become chlorotic and die. Onion bulbs show poor pigmentation because of copper deficiency (El-Hadidi et al., 2016). Looking at these facts, the present research was undertaken to optimize the dose of copper sulfate for increasing the productivity and quality of onion.

\section{MATERIAL AND METHODS}

\section{Field experiment and laboratory analysis}

Four field experiments were conducted, two each during rabi season of 2018 and two during summer season of 2019 at farmer's fields, western zone of Tamil Nadu at Pattiyarkovilpathy, Theethipalayam and Narasipuram villages of Thondamuthur block, Coimbatore district, Tamil Nadu, India. Initial soil sample was collected from 0-15 cm depth and analyzed for various physico-chemical and chemical characteristics (Table 1). Onion variety local was used as a test crop and cropping system was irrigated.

Table 1. Details of analytical procedures employed in soil and plant sample analysis

\begin{tabular}{|c|c|c|}
\hline Parameters & Methodology & References \\
\hline $\begin{array}{l}\text { Physico-chemical } \\
\text { Properties Soil } \\
\text { reaction }(\mathrm{pH})\end{array}$ & $\begin{array}{l}\text { Potentiometry }(1: 2.5 \\
\text { soil : water suspension }\end{array}$ & (Jackson, 2005) \\
\hline $\begin{array}{l}\text { Electrical } \\
\text { conductivity }\end{array}$ & $\begin{array}{l}\text { Conductometry (1:2.5 } \\
\text { soil: water suspension) }\end{array}$ & (Jackson, 2005) \\
\hline $\begin{array}{l}\text { Chemical } \\
\text { Properties Soil } \\
\text { Organic Carbon }\end{array}$ & $\begin{array}{l}\text { Chromic acid wet } \\
\text { digestion method }\end{array}$ & (Wakley and Black. 1934) \\
\hline \multicolumn{3}{|l|}{ Available nutrients } \\
\hline Nitrogen $(\mathrm{N})$ & $\begin{array}{l}\text { Alkaline permanganate } \\
\text { method }\end{array}$ & (Subbiah and Asija, 1956) \\
\hline Phosphorus (P) & Olsen's method & (Olsen et al., 1954) \\
\hline Potassium (K) & Neutral $\mathrm{N} \mathrm{NH}_{4} \mathrm{OAC}$ & $\begin{array}{l}\text { (Stanford and English, } \\
\text { 1949) }\end{array}$ \\
\hline $\begin{array}{l}\text { DTPA Zn, } \mathrm{Cu}, \mathrm{Fe} \\
\text { and Mn Plant } \\
\text { sample analysis }\end{array}$ & $\begin{array}{l}\text { DTPA extraction, AAS } \\
\text { method }\end{array}$ & (Lindsay and Norvell, 1978) \\
\hline $\mathrm{Cu}$ & $\begin{array}{l}\text { Triple acid digestion } \\
\text { and AAS method }\end{array}$ & (Lindsay and Norvell, 1978) \\
\hline Quality parameters & - & Ranganna, S. 1997 \\
\hline
\end{tabular}

\section{Experimental design}

Totally five treatments comprising of varied Cu levels $\left(0,2.5,5.0,7.5\right.$ \& $10.0 \mathrm{~kg} \mathrm{CuSO}_{4}$ ha $\left.^{-1}\right)$ were replicated four times in a randomized block design. The recommended dose of NPK fertilizers at 30:60:30 kg ha-1 was applied as basal, $30 \mathrm{~kg} \mathrm{~N}$ alone was applied as a top dressing on 30 DAS to all the treatments. Urea as N source, Single super phosphate for $\mathrm{P}$, Muriate of Potash for $\mathrm{K}$ and Copper sulfate for $\mathrm{Cu}$ were used as inorganic fertilizer sources.

Table 2. Initial Soil characteristics

\begin{tabular}{|c|c|c|c|c|c|c|c|c|c|c|c|c|}
\hline \multirow[t]{2}{*}{ L. No } & \multirow[t]{2}{*}{ pH } & \multirow[t]{2}{*}{$\begin{array}{c}E C \\
\left(\mathrm{dS} \mathrm{m}^{-1}\right)\end{array}$} & \multirow[t]{2}{*}{$\begin{array}{l}\text { OC } \\
(\%)\end{array}$} & \multicolumn{3}{|c|}{$\begin{array}{l}\text { Major nutrients } \\
\left(\mathrm{kg} \mathrm{ha}^{-1}\right)\end{array}$} & \multirow[t]{2}{*}{$\begin{array}{c}\mathrm{S} \\
\left(\mathrm{mg} \mathrm{kg}^{-1}\right)\end{array}$} & \multicolumn{5}{|c|}{ Micronutrients (mg kg-1) } \\
\hline & & & & $\mathrm{N}$ & $\mathbf{P}$ & $\mathrm{K}$ & & $\mathrm{Fe}$ & $\mathrm{Mn}$ & $\mathrm{Cu}$ & $\mathrm{Zn}$ & B \\
\hline 1 & 7.3 & 0.40 & 0.45 & 204 & 15.8 & 288 & 22.3 & 15.5 & 7.8 & 0.32 & 0.60 & 0.56 \\
\hline 2 & 7.40 & 0.31 & 0.40 & 185 & 16.8 & 309 & 26.0 & 12.5 & 6.3 & 0.66 & 0.74 & 0.88 \\
\hline 3 & 7.0 & 0.42 & 0.54 & 154 & 14.4 & 240 & 28.2 & 13.1 & 6.8 & 0.57 & 0.81 & 0.74 \\
\hline 4 & 7.7 & 0.50 & 0.60 & 160 & 18.1 & 275 & 20.3 & 16.3 & 8.4 & 0.31 & 0.63 & 0.71 \\
\hline
\end{tabular}

$107|10-12| 2$ 
The crop was grown to maturity with routine cultural operations by imposing the treatments and at harvest bulb yield, dry foliage yield, yield attributing characters and quality parameters like total soluble sugars, ascorbic acid and titrable acidity were recorded besides collecting plant and post-harvest soil samples for analyzing the $\mathrm{Cu}$ availability, its content and uptake in bulb and leaves.

\section{Statistical analysis}

The experimental data collected relating to different parameters were statistically analyzed using the procedure given by Panse and Sukhatme, 1967. The data were subjected to Fisher's method of analysis of variance and the level of significance used in $\mathrm{F}$ test was $\mathrm{P}=0.05$. The critical difference was calculated at 5 per cent probability level whenever $F$ value was found to be significant.

\section{RESULTS AND DISCUSSION}

The soil reaction of the experimental initial soil was neutral in all the locations with $\mathrm{pH}$ values of $7.30,7.40,7.0$ and 7.7 with nil salinity status having the electrical conductivity of $0.40,0.31,042$ and $0.50 \mathrm{dSm}^{-1}$. The organic carbon content was 0.45 , $0.40,0.54$ and $0.60 \mathrm{~g} \mathrm{~kg}^{-1}$ in all four locations. Available nitrogen and phosphorus contents of the soils were low 204, 185, 154, $160 \mathrm{~kg} \mathrm{ha}^{-1}$ and 15.8 , $16.8,14.4$ and $18.1 \mathrm{~kg}^{-1}$ respectively. The values for available $\mathrm{K}$ and S were 288, 309, 240, $275 \mathrm{~kg}$ ha1 and 22.3, 260, 28.2 and $20.3 \mathrm{mg} \mathrm{kg}^{-1}$ respectively. The nutrient status of all the farm soils showed low to medium in organic carbon content, low to medium in available $\mathrm{N}$ and $\mathrm{P}$, high in available $\mathrm{K}$ and S. Micronutrient availability in the soils revealed sufficient status of $\mathrm{Mn}$ and Fe, while many of the farms were deficient in $\mathrm{Zn}$ and $\mathrm{Cu}$ availability. DTPA Copper status in the soils were 0.72, 0.66, 0.57 and $0.81 \mathrm{mg} \mathrm{kg}^{-1}$. The experimental soil was sandy loam.

\section{Yield and DMP}

The results showed that, fresh bulb yield of onion in all four locations ranged from 11.5 to 16.4 $\mathrm{t} \mathrm{ha}^{-1}$ and a mean variation of 12.4 to $15.6 \mathrm{t} \mathrm{ha}^{-1}$. Application of $\mathrm{CuSO}_{4}$ at graded levels increased the onion bulb yield up to $5 \mathrm{~kg} \mathrm{CuSO}_{4} \mathrm{ha}^{-1}$ and thereafter gets decreased. Highest bulb yield of 14.6, 15.3, 16.4 and 16.0 t ha $^{-1}$ was registered in Location 1 , $2,3 \& 4$, respectively with the a mean of $15.6 \mathrm{t} \mathrm{ha}^{-1}$. It was followed by $7.5 \mathrm{~kg} \mathrm{CuSO}_{4} \mathrm{ha}^{-1}$ in all the locations with the mean yield of $15.0 \mathrm{t} \mathrm{ha}^{-1}$ and the lowest bulb yield of $11.8,12.6,13.5,11.5 \mathrm{t} \mathrm{ha}^{-1}$ with a mean of $12.4 \mathrm{t} \mathrm{ha}^{-1}$ was recorded in the NPK control with no $\mathrm{CuSO}_{4}$ in four locations (Table.3 \& Fig.1).

Table 3. Effect of different levels of $\mathrm{CuSO}_{4}$ on the yield, dry matter production and BCR

\begin{tabular}{|c|c|c|c|c|c|c|c|c|c|c|c|}
\hline \multirow{2}{*}{$\begin{array}{l}\text { Levels of CuSO } \\
\quad\left(\mathrm{kg} \mathrm{ha}^{-1}\right)\end{array}$} & \multicolumn{4}{|c|}{ Bulb yield (t ha-1) } & \multicolumn{6}{|c|}{ DMP (kg ha-1) } & \multirow{2}{*}{ BCR } \\
\hline & L1 & L2 & L3 & L4 & Mean & L1 & L2 & L3 & L4 & Mean & \\
\hline 0 & 11.8 & 12.6 & 13.5 & 11.5 & 12.4 & 1093 & 1031 & 1100 & 1036 & 1065 & 3.72 \\
\hline 2.5 & 13.6 & 13.9 & 14.2 & 12.9 & 13.7 & 1123 & 1059 & 1127 & 1063 & 1093 & 4.09 \\
\hline 5.0 & 14.6 & 15.3 & 16.4 & 16.0 & 15.6 & 1227 & 1163 & 1241 & 1165 & 1199 & 4.63 \\
\hline 7.5 & 14.3 & 14.7 & 15.8 & 15.2 & 15.0 & 1163 & 1099 & 1180 & 1105 & 1137 & 4.43 \\
\hline 10.0 & 14.0 & 14.2 & 15.4 & 13.9 & 14.4 & 1109 & 1049 & 1132 & 1057 & 1087 & 4.24 \\
\hline Mean & 13.7 & 14.1 & 15.1 & 13.9 & & 1143 & 1080 & 1156 & 1085 & & \\
\hline SEd & 0.26 & 0.17 & 0.16 & 0.30 & & 32.6 & 33.6 & 30.2 & 30.9 & & \\
\hline$C D(P=0.05)$ & 0.58 & 0.37 & 0.35 & 0.67 & & 76.1 & 78.0 & 69.4 & 71.7 & & \\
\hline
\end{tabular}

A similar trend was observed with respect to the dry matter production of onion in four locations and the DMP in all the locations ranged from 1031 to 1241 $\mathrm{kg} \mathrm{ha}^{-1}$ with a mean range of 1065 to $1199 \mathrm{~kg} \mathrm{ha}^{-1}$. The highest DMP of four locations were $1227,1163,1241,1165 \mathrm{~kg} \mathrm{ha}^{-1}$ with a mean of 1199 $\mathrm{kg} \mathrm{ha}^{-1}$, which was recorded in the treatment that was applied with NPK+5 $\mathrm{kg} \mathrm{CuSO}_{4} \mathrm{ha}^{-1}$ and the lowest DMP of $1093,1031,1100,1036 \mathrm{~kg} \mathrm{ha}^{-1}$ with a mean of $1065 \mathrm{~kg} \mathrm{ha}^{-1}$ was noticed with NPK control with no $\mathrm{CuSO}_{4}$ (Table.3). Response to $\mathrm{CuSO}_{4}$ was found to be very high in the soils having deficient $\mathrm{Cu}$ availability. This could be attributed to the vital functions of copper in plant growth and metabolism. Application of $\mathrm{CuSO}_{4}$ at higher levels up to $5 \mathrm{~kg}$ per ha resulted in the development of good growth of sheath, bulbs and accelerated protein synthesis, bulb formation and better yield of crop. The results are further in accordance with the reports of Chattopadhyay et al. (2004) and Ballabh et al., (2013), who reported that the yield characters are significantly influenced with a higher level of micronutrients like, Zn, B, Mn and $\mathrm{Cu}$ in onion. Bose et al., (2009) stated that the increase in growth and yield might be due to role

Figure.1. Optimizing the rate of copper dose for onion

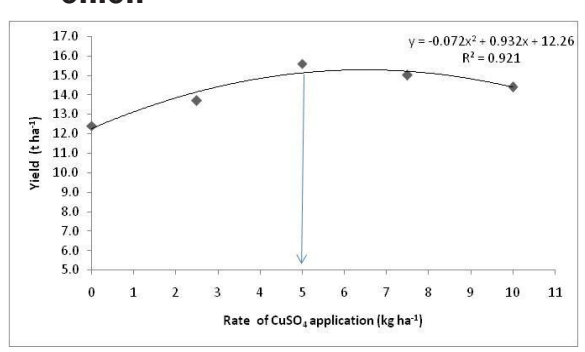

$107 \mid 10-12$ | 3 
of copper as essential for plant metabolism, one of the constituents of certain oxidizing reduction enzymes. Therefore, its role in plant metabolism and participation in oxidation-reduction action, check in certain diseases and there by improved growth of plant and yield. The benefit-cost ratio ranged from 3.72 to 4.63 , a maximum of 4.63 was observed in the treatment with the application of NPK $+5.0 \mathrm{~kg}$ $\mathrm{CuSO}_{4} \mathrm{ha}^{-1}$ and the lowest was noticed in NPK control with no $\mathrm{CuSO}_{4}$ (Table.3).

\section{Cu content and Copper uptake}

The copper content in both onion bulb and foliage was estimated and the uptake was computed. The results showed that application of copper sulfate resulted in increased $\mathrm{Cu}$ content in onion bulb and sheath and it was increased with increasing levels of $\mathrm{CuSO}_{4}$. In onion bulb, copper content in all four locations varied from 6.09 to $12.3 \mathrm{mg}$ $\mathrm{kg}^{-1}$ with a mean variation of 6.16 to $12.0 \mathrm{mg} \mathrm{kg}^{-1}$. In all the locations, the mean value showed the highest $\mathrm{Cu}$ content of 12.3,11.4,11.9,12.2 mg $\mathrm{kg}^{-1}$ with an overall mean of $12.0 \mathrm{mg} \mathrm{kg}^{-1}$ in the treatment that received $\mathrm{NPK}+10 \mathrm{~kg} \mathrm{CuSO}_{4} \mathrm{ha}^{-1}$ which was followed by $7.5 \mathrm{~kg} \mathrm{CuSO}_{4} \mathrm{ha}^{-1}$ addition and the lowest mean values was noticed in the NPK control. With regard to copper content in foliage, the values ranged from 8.46 to $13.7 \mathrm{mg} \mathrm{kg}^{-1}$ with the location mean of 7.61 to $11.1 \mathrm{mg} \mathrm{kg}^{-1}$ (Table 4). A similar trend was observed in the foliage also with the increased values for the increased levels of

Table 4. Effect of different levels of $\mathrm{CuSO}_{4}$ on the $\mathrm{Cu}$ content in onion

\begin{tabular}{|c|c|c|c|c|c|c|c|c|c|c|}
\hline \multirow{3}{*}{ Levels of $\mathrm{CuSO}_{4}\left(\mathrm{~kg} \mathrm{ha}^{-1}\right)$} & \multicolumn{10}{|c|}{ Cu uptake (kg ha-1) } \\
\hline & \multicolumn{4}{|c|}{ Bulb } & \multicolumn{6}{|c|}{ Foliage } \\
\hline & L1 & L2 & L3 & L4 & Mean & L1 & L2 & L3 & L4 & Mean \\
\hline 0 & 6.09 & 6.17 & 6.24 & 6.13 & 6.16 & 8.65 & 8.57 & 8.51 & 8.46 & 8.55 \\
\hline 2.5 & 7.19 & 6.94 & 7.24 & 6.82 & 7.05 & 9.17 & 9.21 & 9.09 & 9.27 & 9.19 \\
\hline 5.0 & 8.73 & 8.59 & 8.67 & 8.49 & 8.62 & 10.9 & 11.1 & 11.0 & 11.3 & 11.1 \\
\hline 7.5 & 9.95 & 9.79 & 9.88 & 9.69 & 9.83 & 11.6 & 12.4 & 11.8 & 12.7 & 12.1 \\
\hline 10.0 & 12.3 & 11.4 & 11.9 & 12.2 & 12.0 & 13.1 & 13.4 & 12.9 & 13.7 & 13.3 \\
\hline Mean & 8.85 & 8.58 & 8.79 & 8.67 & & 10.7 & 10.9 & 10.7 & 11.1 & \\
\hline SEd & 0.26 & 0.17 & 0.16 & 0.30 & & 0.11 & 0.21 & 0.16 & 0.07 & \\
\hline$C D(P=0.05)$ & 0.58 & 0.37 & 0.35 & 0.67 & & 0.24 & 0.46 & 0.35 & 0.15 & \\
\hline
\end{tabular}

$\mathrm{CuSO}_{4}$ application. In all the locations, the highest copper content of 13.1,13.4,12.9,13.7 $\mathrm{mg} \mathrm{kg}^{-1}$ and a mean $13.3 \mathrm{mg} \mathrm{kg}^{-1}$ was recorded in the treatment applied with NPK + CuSO @ $10.0 \mathrm{~kg} \mathrm{ha}^{-1}$ which was followed by $7.5 \mathrm{~kg} \mathrm{CuSO}{ }_{4}$ addition and the values were $11.6,12.4,11.8,12.7 \mathrm{mg} \mathrm{kg}^{-1}$ with a mean of $12.1 \mathrm{mg} \mathrm{kg}^{-1}$. Similarly, the lowest copper content of $8.65,8.57,8.51,8.46 \mathrm{mg} \mathrm{kg}^{-1}$ and a mean of $8.55 \mathrm{mg} \mathrm{kg}^{-1}$ were observed with NPK control with no $\mathrm{CuSO}_{4}$. Copper uptake in bulb and sheath also increased with increasing dose of copper sulphate and the values varied from 7.05 to 18.3 and 6.26 to $11.0 \mathrm{~g} \mathrm{ha}^{-1}$ (mean of 8.55 to 12.3 and 6.52 to $10.4 \mathrm{~g} \mathrm{ha}^{-1}$ ) respectively. In both bulb and foliage, the highest uptake was registered with the application of $\mathrm{CuSO}_{4} @ 10.0 \mathrm{~kg} \mathrm{ha}^{-1}$. In all the four locations, in bulb the highest Cu uptake of 17.2,16.2,18.3,17.0 g ha $^{-1}$ with a mean of $17.2 \mathrm{~g} \mathrm{ha}^{-1}$ (Table 5 ) was recorded with $\mathrm{NPK}+10 \mathrm{~kg} \mathrm{ha}^{-1} \mathrm{CuSO}_{4}$ addition, which was followed by $\mathrm{NPK}+7.5 \mathrm{~kg} \mathrm{ha}^{-1} \mathrm{CuSO}_{4}$ addition and the values were

Table 5. Effect of different levels of $\mathrm{CuSO}_{4}$ on the Cu uptake by onion

\begin{tabular}{|c|c|c|c|c|c|c|c|c|c|c|}
\hline \multirow{3}{*}{ Levels of $\mathrm{CuSO}_{4}\left(\mathrm{~kg} \mathrm{ha}^{-1}\right)$} & \multicolumn{10}{|c|}{ Cu uptake (g ha-1) } \\
\hline & \multicolumn{4}{|c|}{ Bulb } & \multicolumn{6}{|c|}{ Foliage } \\
\hline & L1 & L2 & L3 & L4 & Mean & L1 & L2 & L3 & L4 & Mean \\
\hline 0 & 7.19 & 7.77 & 8.42 & 7.05 & 7.61 & 6.76 & 6.78 & 6.26 & 6.29 & 6.52 \\
\hline 2.5 & 9.78 & 9.65 & 10.28 & 8.80 & 9.63 & 7.44 & 7.53 & 6.94 & 7.15 & 7.27 \\
\hline 5.0 & 12.7 & 13.1 & 14.2 & 13.6 & 13.4 & 9.9 & 10.4 & 9.5 & 9.9 & 9.94 \\
\hline 7.5 & 14.2 & 14.4 & 15.6 & 14.7 & 14.7 & 10.0 & 10.8 & 9.5 & 10.3 & 10.1 \\
\hline 10.0 & 17.2 & 16.2 & 18.3 & 17.0 & 17.2 & 10.4 & 11.0 & 9.7 & 10.5 & 10.4 \\
\hline Mean & 12.2 & 12.2 & 13.4 & 12.2 & & 8.90 & 9.30 & 8.38 & 8.83 & \\
\hline SEd & 0.29 & 0.37 & 0.28 & 0.34 & & 0.14 & 0.21 & 0.21 & 0.21 & \\
\hline$C D(P=0.05)$ & 0.63 & 0.82 & 0.61 & 0.75 & & 0.32 & 0.47 & 0.46 & 0.27 & \\
\hline
\end{tabular}

$107|10-12| 4$ 
14.2,14.4,15.6,14.7 $\mathrm{g} \mathrm{ha}^{-1}$ with a mean of 14.7 $\mathrm{g} \mathrm{ha}{ }^{-1}$. In bulb, the lowest copper uptake of $7.19,7.77,8.42,7.05 \mathrm{~g} \mathrm{ha}^{-1}$ with a mean of $7.61 \mathrm{~g}$ ha $^{-1}$ which was recorded in the NPK control with no $\mathrm{CuSO}_{4}$. Similarly, in foliage, also similar trend was observed and in all four locations, the highest $\mathrm{Cu}$ uptake of $10.4,11.0,9.7,10.5 \mathrm{~g} \mathrm{ha}^{-1}$ with a mean of $10.4 \mathrm{~g} \mathrm{ha}^{-1}$ was recorded with NPK+10 kg ha-1 $\mathrm{CuSO}_{4}$ addition, which was followed by NPK $+7.5 \mathrm{~kg}$ $\mathrm{ha}^{-1} \mathrm{CuSO}_{4}$ and the values were $10.0,10.8,9.5,10.3 \mathrm{~g}$ ha-1 with a mean of $10.1 \mathrm{~g} \mathrm{ha}^{-1}$. In foliage, the lowest copper uptake of $6.76,6.78,6.26,6.29 \mathrm{~g} \mathrm{ha}^{-1}$ with a mean of $6.52 \mathrm{~g} \mathrm{ha}^{-1}$ was recorded in the NPK control.

\section{Figure.2. Effect of Copper sulphate application on} DTPA Cu availability in soil

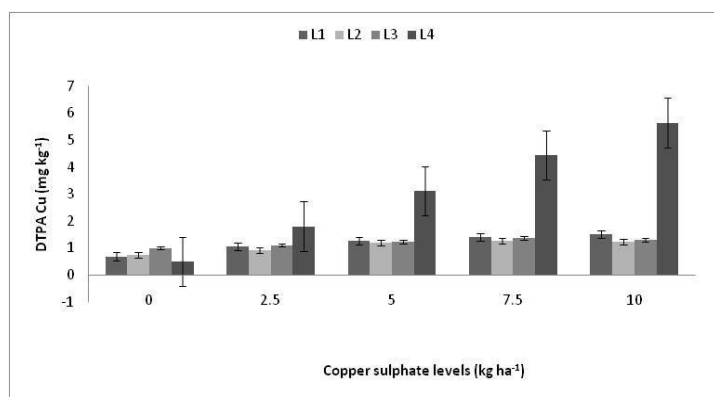

However, the uptake of plant nutrients depends on several factors, such as cultivar, crop environment, soil fertility, fertilization methods (Lee et al., 2009; Yoldas et al., 2011).

\section{Quality parameters}

The quality parameters of onion were significantly influenced by the application of copper sulfate at different levels. The data on total soluble solids, titrable acidity and ascorbic acid content in the bulbs were assessed and reported the table 6 . TSS, titrable acidity and ascorbic acid varied from 10.25 to 14.08 ${ }^{\circ}$ Brix, 0.28 to $0.61 \%$ and 12.9 to $20.1\left(100 \mathrm{~g}^{-1} \mathrm{FW}\right)$ respectively. The highest TSS $\left(14.08^{\circ}\right.$ Brix), titrable acidity (0.61\%) and ascorbic acid 20.1(100 g-1 FW) content was recorded with the application of $\mathrm{CuSO}_{4}$ @5 $\mathrm{kg} \mathrm{ha}^{-1}$ and the lowest was observed in NPK control with no $\mathrm{CuSO}_{4}$ addition. Quality parameters were found to be good under association with the $\mathrm{CuSO}_{4}$ application at increasing levels up to $\mathrm{CuSO}_{4}$ @ $5 \mathrm{~kg} \mathrm{ha}^{-1}$ while the reduction in quality attributes were observed with increasing doses of copper sulfate. The improvement in TSS content in onion bulbs with the application of micronutrients might be attributed to the enhanced metabolic process involved in the biosynthesis of TSS, sugars, ascorbic acid, amino acid and other inorganic constituents. (Acharya et al., 2015). Similar results were reported earlier by Alam et al., 2010, Aske et al., 1492017 \& Tariq et al., 2018.

\section{Cu availability}

Regarding the availability of copper in soil, it ranged from 0.73 to $2.42 \mathrm{mg} \mathrm{kg}^{-1}$ and the availability was found to be sufficient at all levels of $\mathrm{CuSO}_{4}$ addition (Fig.2). Increasing levels of application increased the soil Cu status and in all four locations, application of $10.0 \mathrm{~kg} \mathrm{CuSO}_{4}$ ha $^{-1}$ recorded the highest DTPA Cu of 1.50, 1.24, 1.30, $5.6542 \mathrm{mg} \mathrm{kg}^{-1}$ with a mean of $2.4242 \mathrm{mg} \mathrm{kg}^{-1}$ in soil. The copper availability in post harvest soil showed the sustained status of copper except NPK control, which recorded the lowest value of $0.73 \mathrm{mg} \mathrm{kg}^{-1}$.

Table 6. Effect of different levels of $\mathrm{CuSO}_{4}$ on quality parameters of onion

\begin{tabular}{|c|c|c|c|c|c|c|c|c|c|c|c|c|c|c|c|}
\hline \multirow{2}{*}{$\begin{array}{l}\text { Levels of } \\
\text { CuSO }_{4} \\
\left(\mathrm{~kg} \mathrm{ha}^{-1}\right)\end{array}$} & \multicolumn{5}{|c|}{ TSS } & \multicolumn{5}{|c|}{ Ascorbic acid } & \multicolumn{5}{|c|}{ Titrable acidity } \\
\hline & L1 & L2 & L3 & L4 & Mean & L1 & L2 & L3 & L4 & Mean & L1 & L2 & L3 & L4 & Mean \\
\hline 0 & 11.0 & 10.3 & 11.6 & 11.1 & 10.9 & 13.1 & 14.6 & 12.9 & 16.5 & 14.3 & 0.32 & 0.48 & 0.37 & 0.43 & 0.40 \\
\hline 2.5 & 12.1 & 12.9 & 12.6 & 12.9 & 12.7 & 15.2 & 16.9 & 14.1 & 17.9 & 16.1 & 0.34 & 0.56 & 0.38 & 0.50 & 0.45 \\
\hline 5.0 & 12.4 & 13.4 & 14.1 & 13.9 & 13.5 & 16.5 & 18.9 & 17.9 & 20.1 & 18.4 & 0.36 & 0.61 & 0.48 & 0.52 & 0.49 \\
\hline 7.5 & 12.1 & 11.9 & 13.1 & 12.3 & 12.4 & 16.4 & 17.1 & 16.6 & 17.4 & 16.9 & 0.34 & 0.44 & 0.34 & 0.48 & 0.40 \\
\hline 10.0 & 11.1 & 11.7 & 11.9 & 10.8 & 11.4 & 13.7 & 14.1 & 14.5 & 16.0 & 14.6 & 0.30 & 0.42 & 0.28 & 0.35 & 0.34 \\
\hline SEd & 0.96 & 1.00 & 0.27 & 0.19 & & 0.51 & 0.51 & 0.42 & 0.55 & & 0.06 & 0.05 & 0.07 & 0.02 & \\
\hline$C D(P=0.05)$ & NS & NS & 0.60 & 0.43 & & 1.12 & 1.13 & 0.92 & 1.22 & & NS & 0.10 & NS & 0.04 & \\
\hline
\end{tabular}

This might be due to the effect of the addition of $\mathrm{Cu}$ through fertilisers and also available from inherent properties of soil like, parent material, the effect of organic matter and presence of clay minerals. Similar findings was reported by Kamble and Kathmale (2015).

\section{CONCLUSION}

Relevant Field experiments were conducted to optimize the dose of copper sulfate for aggragaum onion to increase the yield and quality under irrigated conditions. The highest bulb yield of $15.6 \mathrm{t} \mathrm{ha}^{-1}$ with the addition of recommended NPK $+5 \mathrm{~kg} \mathrm{CuSO}_{4}$ ha $^{-1}$ and the lowest bulb yield of 12.4 t ha $^{-1}$ was recorded in NPK control. Mean DMP ranged from 1065 to $1199 \mathrm{~kg} \mathrm{ha}^{-1}$. In addition, the application of copper sulfate increased the $\mathrm{Cu}$ content both in sheath and bulb thus increased $\mathrm{Cu}$ uptake was noticed with increasing levels of $\mathrm{CuSO}_{4}$ and the highest content and uptake was recorded with NPK+10 kg $\mathrm{CuSO}_{4}$ ha $^{-1}$. Regarding the availability of copper in the soil, the availability was found to be sufficient 
at all levels of $\mathrm{CuSO}_{4}$ addition. Increasing levels of copper application increased the soil Cu status and application of $10.0 \mathrm{~kg} \mathrm{CuSO}_{4} \mathrm{ha}^{-1}$ recorded the highest copper availability in soil. Application of $\mathrm{CuSO}_{4} @ 5 \mathrm{~kg} \mathrm{ha}^{-1}$ also registered better quality attributes viz., total soluble solids, ascorbic acid and titrable acidity in onion bulb. The above field experiments conducted to optimize the rates of copper sulfate application to improve the yield and quality of aggregatum onion in four locations at Coimbatore district, showed that, soil application of $5 \mathrm{~kg} \mathrm{CuSO}$ along with recommended NPK @ $60: 30: 30 \mathrm{~kg} \mathrm{ha}_{-1}$ was found optimal for obtaining higher bulb yield (15.6 $\mathrm{t} \mathrm{ha}_{-1}$ ) and better quality in aggregatum onion with a $\mathrm{BC}$ ratio of 4.63 .

\section{ACKNOWLEDGMENT}

The authors greatly acknowledge the financial support rendered by the AICRP-Micronutrients Scheme of Indian Society of Soil Science, Bhopal and Tamil Nadu Agricultural University, Coimbatore for the execution of technical programme, man power and facility support.

\section{REFERENCES}

Acharya, N, Venkatesan, K, Saraswathi,T ad K.S.Subramanian. 2015. Effect of Zinc and boron application on growth and yield parameters of multiplier onion (Allium cepa L. var. aggragatum Don) var.Co 5.

International Journal of Research. 2(1): 757-765

Alam, M.N., Abedin, M.J. and M.A.K.Azad. 2010. Effect of micronutrients on growth and yield of onion under calcareous soil environment. International Research Journal of Plant Science 1(3): 056-061.

Aske V, Jain PK and S.Govind.2017. Effect of Micronutrients on yield, quality and storability of onion cv.

Bhima Super. Trends in Biosciences. (10):1354-1358. 9

Ballabh, K., Rana, D.K. and S.S.Rawat. 2013. Effects on foliar application of micronutrients on growth, yield and quality of onion. Indian Journal of Horticulture, 70(2): 260-265.

Brewester, J.L. 1994. Onions and other vegetable Alliums. CABInternational,Wallingford,UK,p. 36.

Chattopadhyay, S.B. and T.P.Mukhopadhyay. 2004. Response of boron and molybdenum as foliar feeding on onion in tarai soil of West Bengal. Environment and Ecology, 22(4): 784-787.

Donghua Liu, Wusheng Jiang, Cheng Lu, Fengmei Zhao, Yuqing $\mathrm{HaO}$ and Lin Guo. 1994 Effects of copper sulfate on the nucleolus of Allium cepa root-tip cells. Heredilus, 120: 87-90

El-Hadidi, E.M. ; M.M. El-Shazly and Heba M.M. Hegazy. 2016 Effect of N, P and Cu fertilization on onion yield, quality and nutrients uptake. J.Soil Sci. and Agric. Eng., Mansoura Univ., Vol. 7(2): 231 - 236

Fink M., Feller C., Scharpf H.C., Weier U., Maync A., Ziegler J., Paschold P.J.,and K. Strohmeyer. 1999.

Nitrogen, phosphorus, potassium and magnesium contents of field vegetables - recent data for fertilizer recommendations and nutrient balances. Journal of Plant Nutrition and Soil Science, 162: 20071-73.

Jackson, M. L. 2005. Soil chemical analysis: Advanced course (2-Ed) UW-Madison Libraries, Madison,

Wisconsin, p. 798-837. http:parallelpress.library.wisc.edu

Jegadeeswari, D, Chitdeshwari, T and P. Boominathan. 2019. Screening of short duration rice genotypes for Zn use efficiencies. International J. of Experimental Biology and Agricultural Sciences, 7(1): 25- 20533

Kamble, B.M and D.K.Kathmale. 2015. Effect of different levels of customized fertilizer on soil nutrient availability, yield and economics of onion. J. of Applied and Natural Sci., 7(2):817-821

Lakshmi, C.S and C.C. Sekhar. 2018. A review on integrated nutrient management in bulbous vegetable crops. Journal of Pharmacognosy and Phytochemistry, 7, 411-415

Lata Shukla, U.S. Bose and Manoj Kumar Ahirwar.2015. Effect of foliar feeding of micronutrients on growth, yield and income from rabi onion var. Agrifound light red. Annals of Plant and Soil Research 17 (3): 307-310

Lee J., Lee S. 2014. Correlations between soil physicochemical properties and plant nutrient concentrations in bulb onion grown in paddy soil. Scientia Horticulturae, 179: 158-162.

Lee E.J., Yoo K.S., Jifon J and B.S. Patil. 2009. Application of extra sulphur to high-sulphur soils does not increase pungency and related compounds in shortday onions. Scientia Horticulturae, 123: 178217183.

Lindsay, W. L. and W.A, Norvell. 1978. Development of a DTPA soil test for zinc, iron, manganese, and copper1. Soil science society of America journal, 42 (3), 421-428.

Mishra, H.P., Sarkar, C., Viswajith, K.P., Dhekale, B.S. and P.K.Sahu.2013. Instability and forecasting using ARIMA model in aua, Production and productivity of onion in India. Journal of Crop and Weed, 9: 96222101

Olsen, S. R., Cole, C. V., Watanabe. F. S. and L.A.Dean. 1954. Estimation of available phosphorous in soil by extraction with sodium bicarbonate. U. S. Dept. Agri, Circ.,939.

Panse, V.G. and P.V. Sukhatme. 1967. Statistical methods for agricultural workers, ICAR Publications, New Delhi.

Poongothai. S and T. Chitdeshwari.2003. Response of blackgram to multi-micronutrients, Madras Agricultural Journal,90, 442-443

Rashid, M.H.A, Massiah, A.J. and Thomas, B. 2016. Genetic regulation of day length adaptation and bulb formation in onion (Allium cepa L.). Acta Horticulturae, 1143: 7-14

Ranganna, S. 1997. Hand Book of analysis and quality control for fruits and vegetables products. 3 , \& edition, Tata McGraw - Hill publishing company Ltd. New Delhj, 12-16

Rupali Dogra, Ashok K. Thakur and Uday Sharma.2019. Studies on Agronomic Bio-fortification with

$107 \mid 10-12$ | 6 
Micronutrients in Onion (Allium cepa L.) Seed Crop. International Journal of Economic Plants. 235 6(3):136-139

Singh, K.P and G. Kalloo. 2000. Nutrient management in vegetable crops. Fertilizer News 45:77-81.

Subbiah, B and G.L.Asija. 1956.Alkaline Permanente method of available nitrogen determination. Current Science, 25 : 259-260

Tariq A Bhat, Chattoo, MA, Parray, EA, Mushtaq, F, Asif M Rather, Zehra, SB, Hajam, MA and M.D.Shah. 2018. Influence of variying levels of $Z n$ on quality attributes and shelf life of onion in Kashmir. The Parma Innovation Journal, 7(7): 342-345
Vijay Aske, P.K. Jain, Narayan Lal and Govind Shiurkar.2017. Effect of Micronutrients on Yield, Quality and Storability of Onion cv. Bhima Super. Trends in Biosciences 10 (6): 1354-1358

Walkley AJ and C.A.Black. 1934 An estimation of the digestion method of determining soil organic matter and proposed modification of the chromic acid titration method. Soil Science. 37:29-38.

Yoldas F., Ceylan S., Mordogan N. and B.C.Esetlili. 2011. Effect of organic and inorganic fertilizers on yield and mineral content of onion (Allium cepa L.). African Journal of Biotechnology, 10: 11488-11492. 